\title{
Academics' Experience of Implementing E-Learning in A South African Higher Education Institution
}

\author{
Mncedisi Christian Maphalala ${ }^{1}$ \& Olufemi Timothy Adigun ${ }^{2}$ \\ ${ }^{1}$ Department of Curriculum and Instructional Studies, Faculty of Education, University of Zululand, KwaDlangezwa, \\ South Africa \\ ${ }^{2}$ Department of Educational Psychology and Special Education, Faculty of Education, University of Zululand, \\ KwaDlangezwa, South Africa \\ Correspondence: Olufemi Timothy Adigun, Department of Educational Psychology and Special Education, Faculty of \\ Education, University of Zululand, KwaDlangezwa, South Africa.
}

Received: August 18, 2020

Accepted: September 16, 2020

Online Published: September 22, 2020

doi:10.5430/ijhe.v10n1p1

URL: https://doi.org/10.5430/ijhe.v10n1p1

\begin{abstract}
This study sought to explore the experiences of academics with the use of e-learning to support teaching and learning at a South African university. The theory underpinning the study was the Unified Theory of Acceptance and Use of Technology (UTAUT). The study adopted a qualitative design using ten purposively selected academic staff and one IT specialist at a South African university. Semi-structured interview was used to gather the data that were used to answer the research questions. Data were analysed using thematic content analysis. The following themes resulted from the analysis: technical support and training for e-learning; Information Communication Technology infrastructure and internet accessibility; uptake of e-learning and the use of the Learning Management System; content development for e-learning; and evaluation of teaching effectiveness using e-learning. Based on the findings, periodic updates and training on the new changes should be made to the university's e-learning platforms, provision of timely technical support to academics in order to sustain positive user experiences of e-learning were recommended.
\end{abstract}

Keywords: e-learning, academics, learning management system, higher education, unified theory of acceptance and use of technology

\section{Introduction}

\subsection{Background to the Study}

The educational system in Sub-Saharan Africa is sandwiched between contextual and systemic challenges (Bozalek \& Ng'ambi, 2015; Leibowitz, 2012), but is not without boundless possibilities created by emerging technologies. South Africa as an independent nation is not immune to either challenge, created by and inherited from past colonial educational policies, but it does have access to the benefits presented by technologies in the $21^{\text {st }}$ century. In the educational sector, particularly in the post-secondary strata, South Africa has enacted various policies such as the National Plan for Higher Education (Department of Education [DoE], 2001) and The White Paper for Post-School Education and Training (Department of Higher Education and Training [DHET], 2013) to address the challenges in the sector through information communication technologies (ICT). Interestingly, ICT have permeated the higher educational sphere and have thus influenced teaching and learning processes. The application of ICT in the teaching and learning process, otherwise known as e-learning, is described as an expanded digitalised, multimedia online learning environment that supports conventional face-to-face teaching and learning (Biehl \& Prescott, 2013). Through e-learning, course content and knowledge sharing is made possible among individuals or groups of learners and their instructors, irrespective of their location or distance from one another. In other words, e-learning has the potential to address educational inequalities and provide a more inclusive educational environment.

In recent times, the Learning Management System (LMS) (Anand \& Eswaran, 2018; Mahabeer \& Pirtheepal, 2019) has become the e-learning platform used by Higher Education Institutions (HEIs).

"It is a self-contained webpage with embedded instructional tools that permit faculty to organise academic content and engage students in their learning" (Gautreau, 2011, p. 2).

For the academic staff of HEIs, the LMS has provided opportunities for online interaction with students, with 
centralised information about the students' progress. Hence, the use of e-learning and the interest of academic communities in South Africa and some other Sub-Saharan African nations have increased steadily in the last couple of years. In the context of HEIs in South Africa, e-learning remains an important tool for the facilitation of virtual learning engagements that are self-directed and self-regulated. Interestingly, e-learning also enhances the motivation and active participation of students in the learning process (Adigun, 2020; Millham et al., 2014). Among other things, e-learning increases access to education via flexible and cost-effective approaches. While e-learning activities involve academics (teachers, tutors or lecturers) and learners, much effort is required by the academics in the various HEIs in terms of the learning objectives, learning content, processes, evaluations and the assessment of the knowledge gained during the virtual teaching and learning processes. In other words, the implementation, usage, management and sustenance of elearning approaches to education and learning in HEIs depend largely on the academics.

Previous literature has expanded the knowledge of students' experiences of e-learning (Arthur-Nyarko \& Kariuki, 2019; Bagarukayo \& Kalema, 2015; Hamid et al., 2009) but a lot of knowledge gaps still exist among academics about elearning experiences, especially in the South African context. Marimo et al. (2013) opine that behavioural intentions, attitudes and perceptions are the essential factors among academics that influence their adoption and use of e-learning platforms for academic instruction. In other words, Marimo et al. (2013) believe that the experience of academics with the implementation, use and adoption of e-learning platforms may be influenced by their behavioural intentions, attitudes and perceptions. Irrespective of the aspects of the academics' attitudes towards or perceptions of e-learning, they have to have the requisite skills in terms of training on the use of the LMS and have technical support as these are critical to their competency in content development, management and e-facilitation (Yiong et al., 2008). Unfortunately though, Sife et al. (2007) have revealed the extent of the technological support and training received by academics at HEIs in terms of the integration and usage of ICT as a tool for e-learning. These authors state that academics in the HEIs from Africa are plagued by systemic challenges and have limited skills required for the implementation and integration of e-learning. Furthermore, there is a deficit in e-learning policies in many of the African HEIs, and a lack of technical and administrative support for the academics for the implementation and use of the e-learning facilities (Sife et al., 2007). Regrettably, such deficits have a varied impact on the academics' awareness, experiences and attitudes towards e-learning. In a recent account by Makgato (2014), the lack of substantial support and assistance from the technical department is reported as a majored hurdle that prevents effective and efficient usage of e-learning facilities in various HEIs.

Irrespective of the level of technical support provided or training received by academics for the implementation and usage of e-learning platforms, the place of the Internet in online learning cannot be overemphasised. In the present age, access to fast Internet services remains a powerful tool for accessing and disseminating information which is essential for educational growth and development. Hence, academics in the HEIs depend largely on access to uninterrupted internet services for the effective delivery of e-learning. In recent times though the issue of internet access in HEIs has been the subject of unending debates. For instance, Oyedemi (2012) states that a reasonable percentage of South Africans have access to the Internet, however, most Internet users have expressed concerns about their limited broadband Internet access. As indicated by Gillwald et al. (2018), while many HEIs in South Africa are faced with the high cost of Internet access, academic users are also discouraged by their limited access and poor connection speeds. In both the University of Fort Hare, South Africa (Letseka, 2001) and the University of Botswana, Botswana (Kabonoki, 2008), the advancement of e-learning has been hampered by the low rate and speed of the Internet connectivity while in Nigeria, Internet facilities and access in virtually all public HEIs are lacking. In fact, Bankole and Babalola (2012); and Ogunrewo and Odusina (2010) states that most academics in Nigeria access the Internet at cybercafés where they personally pay for the Internet services, or they access it through personal hotspot links from their mobile phones to their computers or from their handheld broadband Internet modems connected to their computers.

It should be noted that e-learning is not just the use of computer devices in education, but rather a means of expanding educational frontiers and the advancement of learning potential. Access to fast Internet connections is therefore paramount for virtual teaching and learning activities via the various e-learning platforms which provide opportunities to distribute and communicate learning content to learners, promote real-time online assessments, provide real-time chat rooms and enable collaborative projects among learners (Adigun, 2017; Uziak et al., 2018). As earlier stated, teaching and learning activities on the various e-learning platforms (for example, LMS, Moodle and Blackboard, among others) require a large amount of effort by the academics. While the LMS provides varied teaching and learning opportunities, the experiences of the academics in terms of its uptake and use may vary based on several factors which include but are not limited to: the performance and effort expectancies; the ease of on-campus internet access; the instructor's teaching style (Fresen, 2011); university support of the e-learning activities; social influences; the perceived easiness of use; and time (Siemens, 2006). There has been some obscurity about the perceived influence of 
time on academics' experiences with using e-learning platforms, especially the LMS (Siemens, 2006), but studies have established that instructors and/or academics are inclined to take-up, use and engage learners on the LMS when it has a user-friendly design (Coleman \& Mtshazi, 2017; Govender \& Govender, 2014; Sackstein et al., 2019).

Earlier studies by Bagarukayo \& Kalema (2015); and Govender \& Govender (2014) reveals the perceptions and experiences of lecturers with the use of LMS. In particular, lecturers examined by James (2010) and Govender and Govender (2014) expressed their satisfaction with how the LMS enabled them in facilitation large classes, enhance their assessment strategies and provided better opportunities for them to meet the learning needs of learners with diverse needs. Additionally, a 2017 study by Coleman and Mtshazi among some lecturers in a South African university reveals that the LMS has a great level of acceptance among the academic staff of that university. According to the duo, the academic staff are satisfied with the reliability of the system and are also comfortable with the interface of the LMS (Coleman \& Mtshazi, 2017). Most lecturers examined by Sackstein et al. (2019) showed a higher level of satisfaction with the LMS and they ascribe its perceived ease-of-use for students' monitoring, content uploads, communication, assessments and students' tracking as factors that motivate them to use the LMS in their university. Nevertheless, regardless of the benefits attributed to the LMS, Gautreau (2011) has established that some lecturers are unwilling to use it for teaching purposes. According to Gautreau (2011), many academic staff are not comfortable with the complexities of the LMS interface or with the complicated tasks attributed to the creation and uploading of such learning content. Also, some of the other academic staff who participated in the study by Sackstein et al. (2019) sees the use of the LMS as additional work and are therefore are not motivated to use the e-learning platform to teach their students.

While studies have established the significance of the LMS in HEIs as well as interaction between the students and teachers, Holmes and Prieto-Rodriguez (2018) put forward the importance of the curriculum and its contents which form the basis of online student-teacher interactions. There is no doubt that curriculum contents remain a vital component of teaching and learning in HEIs, and curriculum and course content planning, creation, delivery and implementation is considered the duty of the lecturers/academics in HEIs. All of this must also be done in a way that expands the learning opportunities for the learners. It is interesting to note that while online teaching presents varied opportunities in place of face-to-face teaching (Kumar \& Al-Samarraie, 2018; Yamo, 2017), this change is not without challenges. For example, the lecturers/academics have to devise ways to provide further explanations of course contents to learners using immediate concrete examples, to make up for the lack of face-to-face contact with these learners. Kebritchi et al. (2017) posit that course content issues vis-à-vis the development, the infusion of multimedia into the content, pedagogical strategies and the learners' learning styles are challenges associated with the uptake and usage of the LMS among academics, especially in developing countries. Additionally, while it is imperative that uploaded course content should be presented in a manner that fosters the learners' skills, accessibility to efficient Internet facilities, overly strenuous processes of curriculum content development, uploading and implementation of the content, as well as difficulties in securing technical support may endanger LMS usage in African HEIs.

Regrettably at present, in addition to the strenuous process of content development and implementation for e-learning, there also seem to be challenges with the assessment processes of the learning objectives for e-learners in South African HEIs. Stressing the importance of assessments for e-learning, Wright (2014) advances that the assessments of online teaching should be harmonious with both the objectives and the content presented via the LMS. Additionally, Wright states that assessments of e-learning activities must be feasible and accurate. However, studies (Kennedy et al., 2017; Makokha \& Mutisya, 2016) have established that academics in HEIs who have used the LMS have expressed some dissatisfaction with the assessment process on the platform. In their study, Makokha and Mutisya, (2016) reveal that instructors are not all that satisfied with the assessment procedure on the LMS platform. In fact, the delays in assessment feedback and their negative influence on students' academic achievements have been a turn off for instructors (Chawinga, 2016). Irrespective of the experiences gained or the attitude towards the implementation and use of the various e-learning platforms, the impact of technology on teaching and learning processes cannot be undermined.

Ultimately, the revolutionary implication of technology in teaching and learning process, particularly at the postsecondary education level, advances digitalised networking between systems (HEIs), processes (administrators), machines (e-learning platforms, both hardware and software), as well as the people (academics and students) involved in the processes and outputs of the value chain activities. The implication of technology in higher education is obvious in this present time of the novel Coronavirus (COVID-19), when physical/social distancing has become the 'new normal' and communication and interpersonal relationships are fostered through digital platforms or online media. Unfortunately though, the way in which academics in South African HEIs perceive the use and implementation of elearning continues to generate heated debate, a fact which has been underscored in previous studies (Oni \& 
Mavuyangwa, 2019; Padayachee, 2017). Hence, there is a need to further investigate and advance the body of knowledge on the experiences of South African academics in the implementation of e-learning. This present study investigates the academics' experiences of implementing e-learning in a South African higher education institution by attempting to provide answers to the following questions:

1) What are the factors that influence the uptake and use of e-learning by academics in a South African university?

2) What are the experiences of academics with regard to curriculum and content development for e-learning?

\subsection{Theoretical Orientation}

This study which explores academics' experiences of implementing e-learning in a South African higher education institution is hinged on the Unified Theory of Acceptance and Use of Technology (UTAUT), formulated by Venkatesh et al. (2003) (See Figure 1). The theory (UTAUT) which is widely used to describe people's behaviour, acceptance and use of technology vis-à-vis how technology impacts all human spheres, particularly in the educational sector, was developed by Venkatesh et al. (2003) through an appraisal and consolidation of eight previously existing technological use and acceptance models, according to Jong (2009).

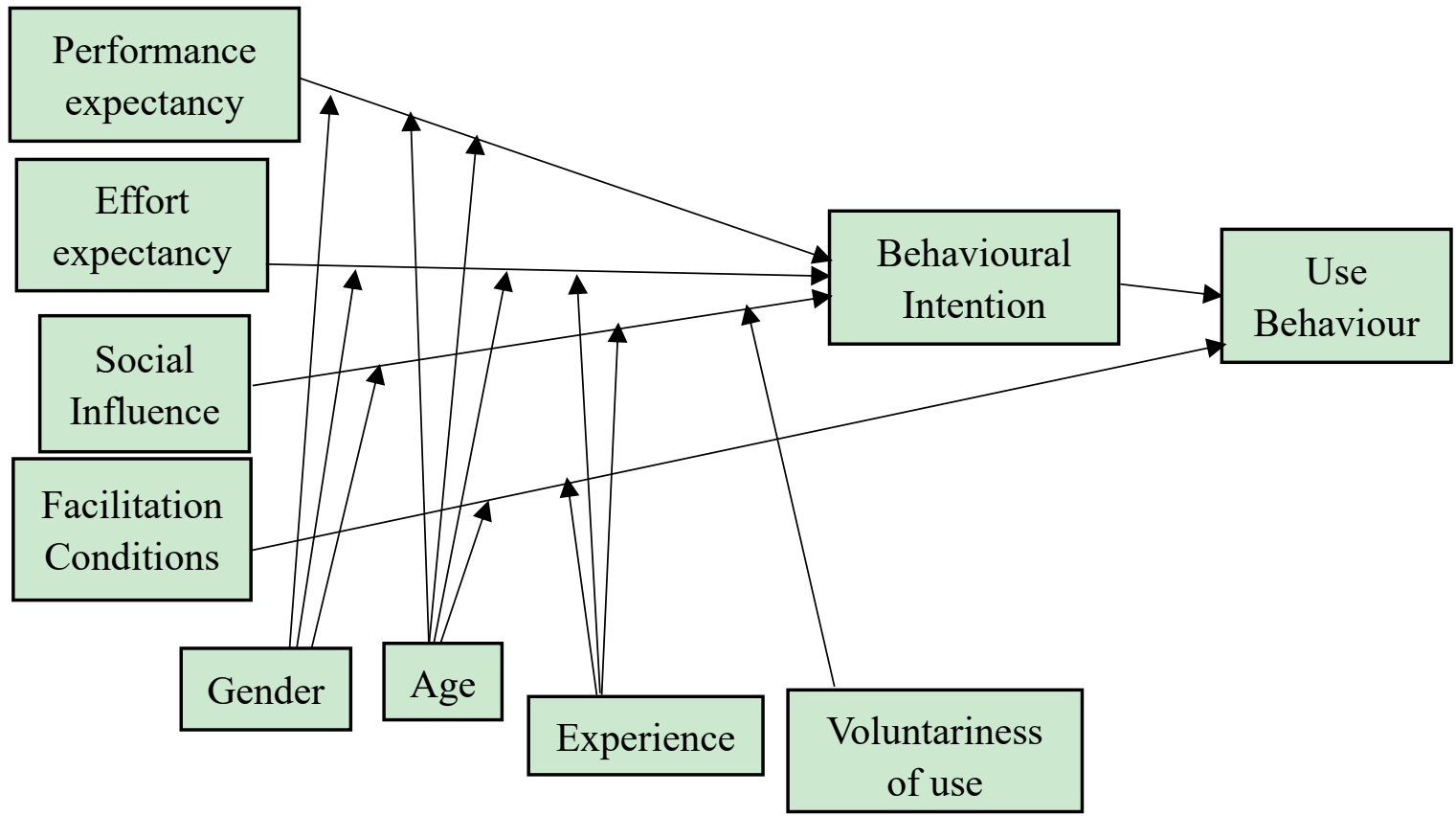

Figure 1. Unified Theory of Acceptance and Use of Technology (UTAUT)

According to Jong (2009), the UTAUT is based on four components (performance expectancy, effort expectancy, social influence, and facilitating condition) and four moderators (gender, age, experience, and voluntariness of use) which best describe the extent to which an individual believes that the application of technology may assist or enhance their job performance. Enhanced job performance is the end point of the intention and use of technology. In higher education in particular, the intention and use of technologies for e-learning is aimed at fostering educational attainment, assessment and/or achievement irrespective of space, distance or time. It is worth noting that effective implementation of e-learning in HEIs is dependent on the users' expectations of efficient workability of the e-learning devices/platforms, the users' expected roles and efforts, the expected personal and social benefits, as well as organisational/technical assistance. Invariably, the aforementioned processes are somewhat influenced by gender, age, experience and voluntariness of use, as indicated by Venkatesh et al. (2003). In this study, while the participants are academics, it is believed that their age, gender or voluntariness to use technology may influence their experiences of e-learning. Thus, based on the robustness, recency and descriptive nature of UTAUT, this study explores academics' experiences of implementing e-learning in a South African higher education institution.

\section{Method}

The interpretivist paradigm and a qualitative descriptive research design were adopted for this study. The qualitative research design was considered suitable for this study because it aimed at exploring the subjective experiences of academics with the use of e-learning at a South African university. The purposive sampling technique was used to 
select ten academics and one information technology (IT) staff member for the study. The ten academics were purposively selected based on the following criteria: they had to have incorporated e-learning into the curriculum and they had to have been teaching undergraduate programmes for at least three years. Also, the IT staff member had to have adequate knowledge of the state of the ICT and had to be ready to provide their perspective on the state of the ICT infrastructure in the institution.

In this study data were collected using a focus group discussion and a semi-structured interview. This was done as we sought to listen to participants explain in their own words their experiences of using and accepting e-learning technologies (Creswell, 2013). A total of ten academics who had already started using the LMS (Moodle) to enhance learning participated in the focus group discussion in order for the researchers to generate data on the experiences of academics with the use of e-learning innovations in teaching and learning at the selected South African university. An audio recorded interview was scheduled with the selected academics and the IT specialist, with the intent to elicit information from the academics about their experiences regarding the uptake and use of e-learning in their university. The interview schedule therefore covered the following key areas:

1) The extent to which Moodle as an LMS was being used in the institution.

2) Technology infrastructure and internet accessibility.

3) The nature of the support provided to successfully implement e-learning.

4) The e-learning vision of the institution.

5) Staff development and training.

6) Challenges in implementing e-learning in the institution

\subsection{Ethical Consideration}

Participants were duly informed about the aim of the study. In line with the ethics of research, the consent (verbal) of the participants was obtained. Participants were assured of the confidentiality, anonymity and privacy of their profiles and responses. The study thus adhered to ethical considerations in research.

\subsection{Data Analysis}

The recorded audio interviews were transcribed, coded and anonymised. A thematic content analysis was performed on the transcribed interviews. The goal of using the thematic analysis was to identify recurring themes in the interviews (Cohen et al., 2011), in order to use the themes to describe and address the research questions. The interviews were coded and organised using the repetitive themes from the transcribed documents. The iterative process of the analysis, comparison and summarisation of the data collected ensured that the research questions could be answered and that a conclusion could be drawn.

\section{Results}

After analysing the data from the focus group discussion and the semi-structured interview with the study participants, five themes emerged about the academics' experiences of implementing e-learning in the institution. The researchers prompted the participants to respond to research question one on the factors that influenced the uptake and use of elearning among the academics in the selected South African university. Based on the responses of the participants, the common themes were (i) technical support and training for e-learning, and (ii) ICT infrastructure and internet accessibility.

\section{(i) Technical support and training for e-learning}

The university provided training on the use of the Learning Management System, but it was inadequate according to the academics. Participants indicated that there was a lack of continuous technical support when they required it. In support of this assertion, Academic B said:

Some lecturers had not attended any training and those may lack of confidence in using Moodle effectively. There are so many academics and therefore one or two training workshops may not be enough to build capacity throughout the whole university. I have attended one workshop and I feel I still need to learn to do more things to diversify the learning activities on Moodle. It is therefore necessary to continuously hold training for us to gain more knowledge and confidence in using Moodle.

Academics believed that e-learning played an important role in enhancing students' academic performance. They did, however, note that students' success would undoubtedly increase if technical support and training were provided on a regular basis. Academic I said: 
Whilst some of us see the value of e-learning, our downfall is lack of technical support. We face a number of system failures and we get stuck, sometimes you get lucky through trial and error, you manage to get through or ask another colleague to assist.

\section{(ii) ICT infrastructure and internet accessibility}

The technological revolution has enabled universities to integrate technology into their educational processes to enhance teaching and learning. In order to do so, connectivity is paramount. Wi-Fi connectivity will therefore ensure that every student, no matter where they are on campus, can access the internet to further their studies. The findings in the study showed that the institution had rolled out Wi-Fi, however it was struggling to keep up with students and staff's expectations of a reliable and fast wireless connectivity everywhere on campus.

IT specialist A had the following to say:

The availability of Wi-Fi around the institution has increased over the years, especially around the office areas and the lectures rooms. There is still a huge need for more hot spots though because some areas still don't have access to Wi-Fi.

An academic supported the view that whilst Wi-Fi connectivity had improved on campus, it had not yet reached acceptable levels of performance and was not accessible throughout campus. Academic B had this to say:

I would like to maybe comment on the Wi-Fi. I think measures have been put in place and we do really appreciate that, especially along the corridors and so on. But I think not sufficient Wi-Fi is easily accessible to students, because what I noticed... instead of students sitting in proper learning environments that are conducive for them to study, you see them sitting along the steps and they claim that that's where the Wi-Fi is most accessible. So I'm not very good when it comes to technology and this Wi-Fi thing, but maybe they should increase the maybe range or maybe have more areas for students to gain easy accessibility.

Another academic staff member had the following to say about the situation:

WI-FI is important for Internet access, even when students are no longer in lecture halls (Academic F).

Internet connectivity was erratic and unreliable, which impacted negatively on teaching and learning processes. Academic B stated the following in this regard:

With regard to us lecturers, I think there is an issue... you know sometimes during the day it just goes away and then our environment is such that without Wi-Fi we cannot really do much, we are restricted to emails and so on. So maybe we should have some kind of a backup system or some kind of a system that's more what can I use... stronger... the technology for our system.

Accessing the technology was considered a challenge, particularly in relation to e-learning. Most students still did not have laptops so they relied on using computers from the computer laboratories. The computer laboratories were overcrowded as they had to service a student population of 17000 . Computers in the laboratories were also slow, old and inadequate, and some were not even functional. Academic $\mathrm{G}$ had this to say:

Computer labs' computers [are] inadequate when compared with the number of students enrolled.

Another Academic staff member had the following to say about the situation:

Most of [the] computers are not working. [The] few [that] are not working... they do not have [a] network [connection]. Even though there are computers that are functional, a number of them are very slow, which will then affect students in doing their work effectively (Academic E).

Where students did not have personal laptops, they relied on the computers in the computer laboratories to access the internet and online resources. Academic $\mathrm{F}$ believed that:

Computer laboratories are overcrowded. We need more space, or extend the building on campus. [The] computer lab is a very important facility for students because not all students' own computers, they have access the computer in the lab for their learning activities.

The computer laboratories were not always accessible to the students because computer classes were held each day until 19h00. This therefore limited accessibility and students had to wait until the laboratories were available. To illustrate this Academic J said:

The labs are always full, there are always classes taking place there and the Wi-Fi is not strong enough. The classes normally run until 19 h00 and most of the students who stay off campus would have left by then because of transport or safety concerns. 
Research question two sought to explore the experiences of academics with e-learning in the selected South African university. The key themes in the responses to this research question by the participants were categorised based on the participants' views. Their explanations are discussed under three themes, namely (a) the uptake of e-learning and the use of the Learning Management System, (b) content development for e-learning, and (c) the evaluation of teaching effectiveness using e-learning.

\section{(a) The uptake of e-learning and the use of the Learning Management System}

The lecturers understood that they had the important role of transferring knowledge to students via e-learning. The study found that most of the lecturers were willing to teach via e-learning, despite the many challenges they faced. Internet connectivity had become a basic necessity, even in the student residences, as learning was no longer time bound or classroom bound. The study revealed that the university lacked the proper wireless network infrastructure to support the Wi-Fi access that the students needed and expected in all of the residences. Wi-Fi connectivity in the residences was sporadic and unreliable. This situation hindered learning that extended beyond the classroom and could affect students' academic performance. Wi-Fi access had to form part of any institution's basic offering. Academic E had this to say:

Only a few residences have access to it; some had it but at some point it was removed. The reliability is average; it just depends on the time of the day. The reliability is also affected by the number of students connecting at the time.

The university had been using a Learning Management System (LMS) called Moodle since 2009 to optimise and support student learning. The findings indicated that the university had integrated e-learning technologies into its teaching and learning process using Moodle, however, there were still areas that needed to be addressed to realise its full potential in the institution. Academic E believed that:

On the use of Moodle... I think there is a lot of activity that is taking place in there. Even in here in our own faculty there is a lot of activity. We are only glad that we have people like the IT specialist who are willing to assist the people who are not able to navigate through the system.

According to the academics, students had lamented about what they called unreasonable restrictions placed on their Wi-Fi usage. Students were blocked from accessing certain cites and YouTube content, which they deemed useful for their studies. Academic F confirmed the assertion by saying:

Our students have a right to use laboratory computers, but in most cases they complain that they are blocked from accessing some useful information such as videos on YouTube. They are even blocked from downloading videos for study purposes. This makes our work difficult as lecturers, as students complain about so many things that hinder their active participation in e-learning.

Students' participation in online activities was limited. Academics believed that in order for e-learning to be successful, students had to be actively involved in the process. Academic A said:

Most of our students find it difficult, first and foremost, to access computers and when they have access they struggle to navigate their way through Moodle. As a result, some students cannot access information on this platform and miss a number of activities they are supposed to do.

Academic E believed that student training was important and that the institution had to provide ongoing technical support by hiring technical support staff and offering training courses for users. This was evidenced by the following:

We expect our students to be conversant with using Moodle, when there is no one who has ever provided any training for them. We just refer students to Moodle without even thinking whether they will be able log onto the system, let alone [use the] various options available to them (Academic E).

Inability to connect to the server for long periods hindered the eLearning project. This was due to electricity connectivity problems and low bandwidth, and was another constraint to learning. Academic $\mathrm{G}$ had this to say:

If there is no internet connectivity over a long period of time you cannot then expect students to be up-to-date with their work. If there is no electricity [you] immediately lose connection and you can't have access to the internet, and sometimes you do not have provision for the students to work offline.

These challenges made it imperative for the institution to make arrangements to maintain a proper infrastructure, and provide backup generators in case of electricity blackouts.

\section{(b) Content development for e-learning}

The academics lacked skill in designing and developing e-learning activities - they lacked knowledge of how to design courses utilising the technology to promote learning. Course content development was a challenge for most of the 
academics using the Learning Management System. In support of this assertion, Participant B said:

In this institution nobody has ever trained us on how we can develop [the] curriculum for e-learning. We mainly post notices, assignments and notes for students. Personally I would like to learn how to develop interactive activities online which are aligned to the outcomes of my module.

The academics were not using the Learning Management System to its full potential. This was according to Academic I who said:

For me, whilst I use Moodle I feel that there is more that I can do to enhance learning in my module. I need somebody to help me with the alignment of [the] curriculum with technology. How do I ensure that the curriculum I teach [is] appropriate with online teaching methodologies? That integration is still elusive in our programmes.

\section{(c) Evaluation of teaching effectiveness using e-learning}

There was a clear university policy on the evaluation of teaching effectiveness using e-learning. The researchers also wanted to establish if there was a policy among the IHEs on the evaluation of teaching effectiveness using e-learning. The study revealed that evaluations were not being conducted, so neither staff nor students using the Learning Management System in the institution could assess the performance of the academics and the usefulness of the system.

Assessments had not been integrated into the e-learning process. This was according to Academic B, who said:

We are still scratching the surface in terms of e-learning in the institution, I agree with my colleague... in my case I would need to conduct a formative assessment on a continuous basis, and I am not sure how I can design user friendly assessment tasks online and be able to easily assess those activities using technological tools online, without having to print them for the purposes of marking. Assessment is an integral part of learning. I shouldn't continue doing assessments manually when we have a system which is underutilised.

Academics wished to provide feedback on how e-learning could be improved upon to cater for their needs. This was according to Academic E, who said:

I think that the university should know how we feel about the e-learning. Even though it is useful, we feel that there are a number of issues that need to be attended to in this Moodle.

The academics believed that as users of e-learning platforms they should be in a position to determine the extent to which e-learning was effective in the institution, from their and their students' points of view. Academic $G$ had this to say:

The evaluation of any programme or initiative provides pointers on its effectiveness so that the areas of weaknesses can be attended to. Moodle was implemented in 2009 [and] since then we have not evaluated its impact in the institution. We continue as if everything is normal and nothing needs to be fixed. We can benefit a lot from the exercise, I support it personally.

\section{Discussion}

Higher Educational Institutions (HEIs) in the $21^{\text {st }}$ century, particularly in the last decade, have witnessed the dynamics of the interplay with technology. Essentially, HEIs have leveraged on the advantages presented by technology and the Internet to provide and/or enhance education for all learners at their institutions (Arthur-Nyarko \& Kariuki, 2019; Cloete, 2017; Fresen, 2011; Gillwald et al., 2018). This has been done irrespective of their locations, using various means including but not limited to the LMS. Users of these platforms for e-learning must be adequately trained in order for these platforms to be utilised effectively, as previously stated by Bagarukayo and Kalema (2015); Makgato (2014); Padayachee (2017); Sife et al. (2007); and Yiong et al. (2008). This current study established the fact that South African HEIs have provided training for academics/lecturers on the use of the LMS. Bagarukayo and Kalema (2015), in a critical review of e-learning usage among some lecturers in a South African University, also revealed that academics/instructors in South Africa had received the needed ICT-related training. The duo stated that as ICT was critical to ensuring e-learning, university administrators had to be very conscious of the fact that financial efforts expended on the introduction of an LMS could amount to nothing when the academics/instructors lacked the requisite knowledge of the basics of using the LMS platform.

In the last decade, South African universities have adopted various e-learning platforms and are thus striving to favourably compete with other universities across the globe in the higher education domain. Makgato (2014); and Padayachee (2017) have also acknowledged the efforts of HEIs in training academics/instructors on the intricacies of e-leaning towards effective and efficient use for learning engagement. However, this current study established that although the academics in the HEI studied were trained on the use of the various universities' e-learning platforms, 
continuous technical support for these academics for the effective deployment and use of the e-learning platform was lacking. In other words, the participants of this study indicated that just a few days of training were not sufficient to build the required skills and confidence they needed to use Moodle and other e-learning apparatus effectively. This finding supports the earlier submissions of Bagarukayo and Kalema (2015); Fresen (2011); Rubaai and Hashim (2019); and Sife et al. (2007), who all stated that adequate training and retraining of academics is one of the enormous challenges facing the effective use of e-learning.

This further implies that when users are not knowledgeable about the platform and they are not skilled on how to navigate the interface, they may become discouraged with its use. Hence, the principle of the UTAUT's core components of performance expectancy, effort expectancy, social influence and facilitating conditions may be undermined. This current finding corroborates what Sife et al. (2007), as well as Rubaai and Hashim (2019) pointed out: that systemic challenges and limited skills required for the integration and implementation of e-learning, occasioned by a lack of technical support, prevents the effective usage of e-learning in various HEIs. Makgato (2014) also remarked that a lack of substantial support and assistance from the technical department is a major hurdle that prevents effective and efficient usage of e-learning facilities in various HEIs.

In South Africa, Internet connectivity has increased considerably over time, according to Bagarukayo and Kalema (2015); Gillwald et al. (2018); Greyling (2018); Mahabeer and Pirtheepal (2019); and Oni and Mavuyangwa (2019), when they acknowledged the rapid increase in digital access and Internet connectivity of South Africans. Internet connectivity has also permeated into HEIs in South Africa, which the participants of this study attested to. And although the findings in this study have shown that the institution studied has Internet connectivity, its speed, effectiveness and reliability are questionable. In other words, the Internet connectivity in the South African University examined has not yet reached acceptable levels of performance as it is erratic, unreliable and is not always accessible everywhere on campus. This in turn impacts negatively on teaching and learning engagements via the LMS in this university.

Oyedemi (2012) also noted the challenges of Internet viability and access in some South African universities. He averred that the unavailability of Internet access across South African universities mirrors previous disparities in South Africa. Currently, as indicated by this study, academics are constrained from effectively implementing e-learning due to erratic Internet access and connectivity (Bagarukayo \& Kalema, 2015), and accessing the technology for e-learning remains a challenge. In addition to these technical challenges, previous studies have also shown that many HEIs in South Africa are faced with the high cost of Internet access. Thus academic users are discouraged by their limited access, the slow connection speeds and the high costs (Bankole \& Babalola, 2012; Gillwald et al., 2018).

Inability to connect to the server for long periods hinders the e-learning project and remains a constraint to the uptake and use of e-learning. Academics have expressed their dissatisfaction about this level of Internet access in the university for both staff and students, but the university lacks the proper wireless network infrastructure to support the teaching and learning processes on the university's LMS. This current finding contradicts the findings of Letseka and Pitsoe (2014), as well as those of Letseka et al. (2018) who presented the University of South Africa as the largest university in Sub-Saharan Africa based on its ability to efficiently utilise the LMS as a medium to achieve virtual teaching and learning. This study revealed that the academics at the university studied have resorted to accessing the internet privately, which corroborates the findings of Coleman and Mtshazi (2017); Govender and Govender (2014) Letseka (2001); as well as Ogunrewo and Odusina (2010), who all noted that academics in African HEIs personally sourced private Internet connections when faced with serious difficulties accessing the Internet on campus. Ogunrewo and Odusina (2010) stated that the academics from a Nigerian university do not rely on the Internet connection provided by their university. Instead they also resort to accessing the LMS platform privately to ensure Internet connectivity quickly and without stress to provide virtual teaching. The creation and development of content for e-learning is an important concept in virtual teaching and learning. Virtual teaching is incomplete without adequate and explicit content designed in a student-centred manner (Holmes \& Prieto-Rodriguez, 2018), and this study has noted that academics are struggling with content creation for use on e-learning platforms. This is due to the fact that the participants lack adequate skills needed for designing and developing interactive e-learning activities. The participants are thus not using the Learning Management System to its full potential. This is congruent to the assertions of Kennedy et al. (2017); Kumar and Al-Samarraie (2018); Makokha and Mutisya (2016); and Yamo (2017), as they also established inadequacies in the proficiencies of e-learning instructors with regards to use and navigation of the various e-learning platforms. This result is not surprising as the frequency of use of the e-learning platform is reduced due to the erratic Internet connectivity on the campus studied.

All of this has resulted in the academics in the institution assessed becoming less motivated to create content for elearning. The fact that they cannot afford to continuously provide fast internet connectivity at their personal cost also 
adds to their experience with the use of the LMS towards engaging learning in a virtual community being hampered. Among the various HEIs in developing counties, especially in Sub-Saharan Africa, development and the incorporation of multimedia into course content, pedagogical strategies and learners' different learning styles are some of the challenges associated with the uptake and usage of an LMS (Kebritchi et al., 2017). Of note is the fact that the University of South Africa has overcome these challenges to a large degree as it has fully trained and equipped its academics for virtual teaching and learning activities and it currently boasts of being the largest university in Africa, with over 350,000 students who are registered on their LMS (Letseka \& Pitsoe, 2014; Letseka et al., 2018; NgubaneMokiwa, 2017).

In HEIs, evaluation and assessment of the content taught and learnt is a clear institutional policy. Students are expected to be assessed in order to determine the extent of their knowledge gained and the need for placements and/or promotion. This study engaged participants on their experiences with students' evaluations on the e-learning platform in use, and revealed that evaluations are not being conducted using the Learning Management System. Academics in the university find the LMS platform difficult to navigate and they are not comfortable with online assessments, hence they are still evaluating their students on paper. The fact that the LMS platform is difficult to navigate negates Wright (2014), who advanced the online assessment of online teaching in a manner harmonious with the course objectives and the content taught. This finding does, however, corroborate the reports of Kennedy et al. (2017); and Makokha and Mutisya (2016) who previously established that academics in HEIs expressed some level of dissatisfaction with the assessment process via the LMS. Chawinga (2016) and Makokha and Mutisya (2016) also reported that instructors were not that satisfied with the assessment procedure on the LMS platform. In fact, the delay in obtaining assessment feedback negatively influenced the perceptions of the academics about their students' achievements and turned them off of the idea of using the platform.

\section{Conclusion}

In the higher education space, the impact of technology on the teaching and learning processes cannot be under estimated. The intention, deployment and use of technologies for learning have fostered educational attainment, equality and social justice irrespective of space, distance or time via the various e-learning platforms provided by HEIs. Importantly, effective implementation and use of e-learning in HEIs is dependent on several factors: users' expectations of efficient workability of the e-learning devices/platforms being met; users' expected roles and the effort that they put into using the technology; personal and social benefits being realised; as well as the availability of organisational/technical assistance when required. The foregoing cumulate to form the users' experiences, attitudes and perceptions of e-learning. The study has identified challenges with the use of the e-learning platform at the HEI studied, namely a deficit in ICT infrastructure, erratic Internet access, a low level of technical assistance/support, and inadequate training opportunities for e-learning activities on the university's e-learning platform. This study can conclude that these challenges have combined to dampen the morale of the academics. They lack the enthusiasm to strive to create interactive content/course material for virtual learning and are presently unable to adequately evaluate the students' knowledge gained via the e-learning platform.

\section{Recommendations}

The potential applications and benefits of e-learning are far greater than its challenges. Thus, it is imperative for institutions to resolve the challenges discussed in this article. In the institution studied, where e-learning has not yet reached its full peak due to the challenges of lacking infrastructure, training, faculty, and curriculum development, coupled with the attitudinal factors among the users,

- effort should be made by government agencies and university administrators to expand the broadband Internet access on campus,

- a fast and high speed Internet facility is the core of e-learning activities. Therefore, a public-private partnership could be established in order to ensure that both academics and students have unconstrained and positive teaching and learning interactions via the university's e-learning portal, also,

- academics should periodically be updated and trained on new changes made to the university's e-learning platforms and technical support should immediately be provided to academics and students when needed, and

- the university's e-learning platform should be user friendly in order to sustain positive user experiences, and academics should be trained on content development and students' evaluations for virtual teaching.

\section{Acknowledgements}

Authors appreciate all study participants. 


\section{References}

Adigun, O. T. (2017). Effects of Computer-Assisted Instruction and concept mapping on the academic achievement of students with hearing impairment in Ecology in Ibadan, Oyo State, Nigeria. Journal of Issues and Practice in Education, 9(1), 123-146. Retrieved from https://journals.out.ac.tz/index.php/jipe/article/view/752

Adigun, O. T. (2020). Computer-assisted instruction, project based learning and achievement of Deaf learners in Biology. Journal of E-Learning and Knowledge Society, 16(1), 23-32. https://doi.org/10.20368/1971$8829 / 1135190$

Anand, A., \& Eswaran, S. (2018). A survey of open source learning management systems. Annals. Computer Science Series, 16(1), 185-188. Retrieved from https://www.researchgate.net/publication/328306101_A_Survey_on_Open_Source_Learning_Management_Sys tems

Arthur-Nyarko, E., \& Kariuki, M. G. (2019). Learner access to resources for elearning and preference for elearning delivery mode in distance education programs in Ghana. International Journal of Educational Technology, 6(2), 1-8. Retrieved from https://eric.ed.gov/?id=EJ1228278

Bagarukayo, E., \& Kalema, B. (2015). Evaluation of elearning usage in South African universities: A critical review. International Journal of Education and Development using ICT, 11(2), 168-183. Retrieved from https://www.learntechlib.org/p/151848/

Bankole, O. M., \& Babalola, S. O. (2012). Internet use among undergraduate students of Olabisi Onabanjo University, Ago Iwoye, Nigeria. Library Philosophy and Practice, 812. Retrieved from http://digitalcommons.unl.edu/cgi/viewcontent.cgi?article=1550\&context=libphilprac

Biehl, P. F., \& Prescott, C. (2013). Heritage in the context of globalization: Europe and the Americas. 1st Edn., Springer-Verlag, New York, USA. Retrieved from https://ink.springer.com/book/10.1007/978-1-4614-6077-0

Bozalek, V., \& Dick Ng'ambi, D. (2015). The context of learning with technology. In W.R. Kilfoil (Ed.). Moving beyond the hype: A contextualised view of learning with technology in higher education. Pretoria: Universities South Africa.

Chawinga, W. D. (2016). Teaching and learning 24/7 using Twitter in a university classroom: Experiences from a developing country. E-learning and digital media, 13(1-2), 45-61. https://doi.org/10.1177/2042753016672381

Cloete, A. L. (2017). Technology and education: Challenges and opportunities. HTS Teologiese Studies/ Theological Studies, 73(4), a4589. https://doi.org/10.4102/hts.v73i4.4589

Cohen, L., Manion, L., \& Morrison, K. (2011). Descriptive statistics. Research Methods in Education Seventh Edition. London: Routledge, 35, 622-640.

Coleman, E., \& Mtshazi, S. (2017). Factors affecting the use and non-use of Learning Management Systems (LMS) by academic staff. South African Computer Journal, 29(3), 31-63. https://doi.org/10.18489/sacj.v29i3.459

Creswell, J. W. (2013). Qualitative inquiry: Choosing among five approaches. Los Angeles, CA, 244. Retrieved from https://books.google.co.za/books/about/Qualitative_Inquiry_and_Research_Design.html?id=OJYEbDtkxq8C

Department of Education (DoE). (2001). The National Plan for Higher Education. http://chet.org.za/7manual/media/files/chet_hernana_docs/South\%20Africa/National/National\%20Plan $\% 20$ for $\%$ $20 \mathrm{HE} \% 20 \mathrm{SA} . \mathrm{pdf}$

Department of Higher Education and Training (DHET). (2013). White Paper for Post-School Education and Training - building an expanded, effective and integrated post-school system. Pretoria: DHET. Retrieved from https:/www.gov.za/documents/white-paper-post-school-education-and-training-building-expanded-effectiveand-integrated

Fresen, J. W. (2011). Factors influencing lecturer uptake of e-learning. Teaching English with Technology, 11(1), 8197. Retrieved from https://files.eric.ed.gov/fulltext/EJ1145653.pdf

Gautreau, C. (2011). Motivational factors affecting the integration of a learning management system by faculty. Journal of Educators Online, 8(1), 1-25. https://doi.org/10.9743/JEO.2011.1.2

Gillwald, A., Mothobi, O., \& Rademan, B. (2018). The state of ICT in South Africa. Policy Paper no. 5, Series 5: After Access State of ICT in South Africa. Retrieved from https://researchictafrica.net/after-access-south-africa-stateof-ict-2017-south-africa-report_04/ Accessed 11/07/2020 
Govender, D. W., \& Govender, I. (2014). Technology adoption: A different perspective in a developing country. Procedia-Social and Behavioral Sciences, 116, 2198-2204. https://doi.org/10.1016/j.sbspro.2014.01.543

Greyling, T. (2018). Internet access and its relationship to subjective well-being in a developing region. South African Journal of Economic and Management Sciences, 21(1), 1-12. https://doi.org/10.4102/sajems.v21i1.1841

Hamid, S., Chang, S., \& Kurnia, S. (2009). Identifying the use of online social networking in Higher Education. Proceedings Ascilite. Auckland: Poster. 419-422. Retrieved from https://www.ascilite.org/conferences/auckland09/procs/hamid-poster.pdf

Holmes, K. A., \& Prieto-Rodriguez, E. (2018). Student and Staff perceptions of a learning management system for blended learning in teacher education. Australian Journal of Teacher Education, 43(3), 21-34. https://doi.org/10.14221/ajte.2018v43n3.2

Jong, D. (2009). The acceptance and use of the learning management system. In 2009 Fourth International Conference on Innovative Computing, Information and Control (ICICIC) (pp. 34-37). IEEE. https://doi.org/10.1109/ICICIC.2009.347

Kabonoki, S. K. (2008). Access to technology and readiness to use it in learning. Open Learning: The Journal of Open, Distance and e-Learning, 23(2), 113-121. https://doi.org/10.1080/02680510802051921

Kebritchi, M., Lipschuetz, A., \& Santiague, L. (2017). Issues and challenges for teaching successful online courses in higher education: A literature review. Journal of Educational Technology Systems, 46(1), 4-29. https://doi.org/10.1177/0047239516661713

Kennedy, H., Oboko, R., \& Omwenga. E. (2017). A model for evaluating e-learning systems quality in higher education in developing countries. International Journal of Education and Development using ICT, 13(2), 152-163.

Kumar, J. A., \& Al-Samarraie, H. (2018). MOOCs in the Malaysian higher education institutions: the instructors' perspectives. The Reference Librarian, 1-15. https://doi.org/10.1080/02763877.2018.1458688

Leibowitz, B. (2012). Understanding the challenges of the South African higher education landscape. Community, self and identity: Educating South African university students for citizenship, 3-18. Retrieved from https://www.semanticscholar.org/paper/Understanding-the-challenges-of-the-South-AfricanLeibowitz/29d066bf067ac59a0974107d1249516506f481da

Letseka, M., \& Pitsoe, V. (2014). The challenges and prospects of access to higher education at UNISA. Studies in Higher Education, 39(10), 1942-1954. https://doi.org/10.1080/03075079.2013.823933

Letseka, M. (2001). Information and communication technology (ICT) initiatives at the university of fort hare: Cure or plague? Knowledge, Technology \& Policy, 14(1), 67-78. https://doi.org/10.1007/s12130-001-1004-7

Letseka, M., Letseka, M. M., \& Pitsoe, V. (2018). The challenges of e-Learning in South Africa. Trends in E-learning, 121-138. https://doi.org/10.5772/intechopen.74843

Mahabeer, P., \& Pirtheepal, T. (2019). Online formative assessment tools: lecturers' experiences of using Moodle at a university in South Africa. Journal of Educational Studies, 18(1), 43-63. Retrieved from https://journals.co.za/content/journal/10520/EJC-1d876408e3

Makgato, M. (2014). The challenges of teaching and learning technology subject at schools in South Africa: A case of INSET teachers in Mpumalanga Province. Procedia-Social and Behavioral Sciences, 116, 3688-3692. https://doi.org/10.1016/j.sbspro.2014.01.824

Makokha, G. L., \& Mutisya, D. N. (2016). Status of e-learning in public universities in Kenya. International review of research in open and distributed learning, 17(3), 341-359. https://doi.org/10.19173/irrodl.v17i3.2235

Marimo, S.T., Mashingaidze, S., \& Nyoni, E. (2013). Faculty of Education Lecturers' and students' perceptions on the utilization of e-learning at Midlands State University of Zimbwabwe. International Research Journal of Arts and Social Science, 2(4), 91-98. Retrieved from http://ir.msu.ac.zw:8080/xmlui/handle/11408/1600

Millham, R., Thakur, S., \& Malan, C. (2014). Does self-regulating e-learning assist in secondary school preparation for engineering education? Proceedings of the 2014 Zone 1 Conference of the American Society for Engineering Education, Bridgeport, CT, 2014, 1-5. https://doi.org/10.1109/ASEEZone1.2014.6820666

Ngubane-Mokiwa, S. A. (2017). Implications of the University of South Africa's (UNISA) shift to Open Distance eLearning on Teacher Education. Australian Journal of Teacher Education, 42(9). https://doi.org/10.14221/ajte.2017v42n9.7 
Ogunrewo, J. O., \& Odusina, E. K. (2010). An appraisal of Internet usage among academic staff members of Joseph Ayo Babalola university, Ikeji Arakeji, Osun state, Nigeria. Ozean Journal of Applied, 3(4), 379-385. Retrieved from https://www.semanticscholar.org/paper/AN-APPRAISAL-OF-INTERNET-USAGE-AMONGACADEMIC-STAFF-ODUSINAE.-Babalola/681afe4fce1df0e44baad3cad3eaa21fb103886d

Oyedemi, T. D. (2012). Digital inequalities and implications for social inequalities: A study of Internet penetration amongst university students in South Africa. Telematics and Informatics, 29(3), 302-313. https://doi.org/10.1016/j.tele.2011.12.001

Padayachee, I. (2017). Educator perceptions of virtual learning system quality characteristics. South African Computer Journal, 29(3), 95-126. https://doi.org/10.18489/sacj.v29i3.418

Rubaai, N., \& Hashim, H. (2019). Polytechnic ESL lecturers' acceptance of using Massive Open Online Course (MOOC) for teaching English as a Second Language (ESL). International Journal of Innovative Technology and Exploring Engineering, 8(9), 114-121. https://doi.org/10.35940/ijitee.I7530.078919

Sackstein, S., Coleman, E., \& Ndobe, T. V. (2019). Lecturers' perceptions of learning management systems within a previously disadvantaged university. In Opening Up Education for Inclusivity Across Digital Economies and Societies (pp. 1-28). IGI Global. https://doi.org/10.4018/978-1-5225-7473-6.ch001

Siemens, G. (2006). Learning or management systems? A review of learning management system reviews. Learning Technologies Centre, University of Manitoba.

Sife, A., Lwoga, E., \& Sanga, C. (2007). New technologies for teaching and learning: Challenges for higher learning institutions in developing countries. International journal of education and development using ICT, 3(2), 57-67. Retrieved from https://www.learntechlib.org/p/42360/

Uziak, J., Oladiran, M. T., Lorencowicz, E., \& Becker, K. (2018). Students' and instructor's perspective on the use of Blackboard Platform for delivering an engineering course. The Electronic Journal of e-Learning, 16(1), 1-15. Retrieved from http://www.ejel.org/volume16/issue1/p1

Venkatesh, V., Morris, M. G., Davis, G. B., \& Davis, F. D. (2003). User acceptance of information technology: Toward a unified view. MIS quarterly, 425-478. https://doi.org/10.2307/30036540

Yamo, P. (2017). Learner intrinsic motivation in online social learning platforms: A case study of massive open online course (MOOC) in Thailand. Retrieved from https://eprints.qut.edu.au/108005/5/Pittaya_Yamo_Thesis.pdf

Yiong, B. L. C., Sam, H. K., \& Wah, T. K. (2008). Acceptance of e-learning among distance learners: A Malaysian perspective. Proceedings Ascilite, Melbourne, 541-551. Retrieved from https://www.ascilite.org/conferences/melbourne08/procs/lim.pdf

\section{Copyrights}

Copyright for this article is retained by the author(s), with first publication rights granted to the journal.

This is an open-access article distributed under the terms and conditions of the Creative Commons Attribution license (http://creativecommons.org/licenses/by/4.0/). 